\title{
Author Correction: A consensus S. cerevisiae metabolic model Yeast8 and its ecosystem for comprehensively probing cellular metabolism
}

\author{
Hongzhong Lu, Feiran Li, Benjamín J. Sánchez, Zhengming Zhu, Gang Li (D), Iván Domenzain (D), \\ Simonas Marcišauskas (1D, Petre Mihail Anton (D), Dimitra Lappa (1D, Christian Lieven (1), Moritz Emanuel Beber (D), \\ Nikolaus Sonnenschein, Eduard J. Kerkhoven (1) \& Jens Nielsen (1)
}

Correction to: Nature Communications https:/doi.org/10.1038/s41467-019-11581-3, published online 8 August 2019.

In the original version of this Article, the calculation of the WAP score in the second paragraph of the "Methods" subsection "CLUMPS method to calculate $p$ values of mutation-enriched PDB files" was incorrectly written as "Next, assuming that the uniform distribution of mutations across the protein residues covers the given structure, calculate each WAP score in 10 randomisations to obtain the null distribution." It should read "Next, assuming that the uniform distribution of mutations across the protein residues covers the given structure, calculate each WAP score in $10^{4}$ randomisations to obtain the null distribution."

This has been corrected in both the PDF and HTML versions of this Article.

Published online: 22 October 2020

\footnotetext{
(c) (i) Open Access This article is licensed under a Creative Commons Attribution 4.0 International License, which permits use, sharing, adaptation, distribution and reproduction in any medium or format, as long as you give appropriate credit to the original author(s) and the source, provide a link to the Creative Commons license, and indicate if changes were made. The images or other third party material in this article are included in the article's Creative Commons license, unless indicated otherwise in a credit line to the material. If material is not included in the article's Creative Commons license and your intended use is not permitted by statutory regulation or exceeds the permitted use, you will need to obtain permission directly from the copyright holder. To view a copy of this license, visit http://creativecommons.org/licenses/by/4.0/.
}

(C) The Author(s) 2020 